\title{
The Mineral Carbonation Process of High Calcium Fly Ash under Elevated Carbon Dioxide Pressure and Temperature
}

Jakub Sobala $^{1}$, Natalia Czuma ${ }^{1}$, Jakub Bator ${ }^{2}$, Paweł Baran ${ }^{1}$, Piotr Zabierowski ${ }^{1}$, Katarzyna Zarębska ${ }^{1 *}$

${ }^{1}$ AGH University of Science and Technology in Krakow, Al. Adama Mickiewicza 30, 30-059, Poland

${ }^{2}$ Krakowski Holding Komunalny S.A. W Krakowie Jana Brożka 3 Street, 30-347 Poland

DOI: $10.36348 /$ sijcms.2020.v03i06.003

| Received: 15.07 .2020 | Accepted: 25.07.2020 | Published: 13.08.2020

*Corresponding author: Katarzyna Zarębska

\section{Abstract}

Over the last years, the management of municipal solid waste (MSW) has been renovated and modernized. Timely treatment or storage of municipal waste does not, however, solve the problem of the threat MSW may pose for human life and environment. Therefore, projects of modern thermal plants for the processing of municipal solid waste, such as eco-incineration plants, have been launched on the market. It is not only possible to carry out the process of utilization of MSW, but also to obtain renewable energy. The result of MSW incineration is fly ash and bottom ash. In the fly ash composition, there are present chemical compounds such as silicon dioxide, magnesium oxide, aluminum oxide and calcium oxide. The carbonation process is a process in which calcium or magnesium oxide may react with carbon dioxide, forming carbonates. The mineral carbonation is possible with the use of high-calcium fly ash as one of the substrates of this chemical reaction. As a result, it produces carbonates which are not harmful to the environment as well as to humans. The idea of the experiment was to carry out the process of mineral carbonation of fly ash from the thermal treatment plant of municipal solid waste. The whole process was carried out at elevated pressure, and temperatures. After the experiment, several instrumental analyses were performed on the tested samples, such as XRD analysis, SEM scanning electron microscopy and IR infrared spectroscopy. The free calcium content was determined.

Keywords: Municipal Solid Waste, Fly Ash, Mineral Carbonation Process, waste utilisation, carbon dioxide, emission reduction.

Copyright @ 2020: This is an open-access article distributed under the terms of the Creative Commons Attribution license which permits unrestricted use, distribution, and reproduction in any medium for non-commercial use (NonCommercial, or CC-BY-NC) provided the original author and source are credited.

\section{INTRODUCTION}

Municipal solid waste, commonly known as MSW, poses a threat not only to human health but also influences the functioning of the natural environment. It is a mixture of various types of waste. The main components of municipal waste include biomass, plastics, paper, food residues and metals. At present, it is estimated that about 1 billion tons of municipal waste is produced worldwide during the year [1]. Currently, the technology of thermal treatment of MSW is subject to continuous modernization, thanks to which MSW can be used as a renewable energy source. For several years, research on thermal treatment of municipal waste with the simultaneous generation of electricity has been conducted worldwide. Due to this, it has been possible to reduce the emission of greenhouse gases to the natural environment, and thus to control their generation following acceptable standards [2]. In 2015, about $35 \%$ of municipal waste was thermally treated. Thermal treatment of municipal waste results in significant amounts of by-products of combustion [3].
Fly ash from the thermal treatment of MSW often has similar properties to those of hard coal and lignite. They are also characterized by a similar chemical composition as their crystal structure consists mainly of silicon oxide, aluminum oxide and calcium oxide [4]. Municipal waste management has gained a fast pace in the last few decades. The development of the economy made it necessary to try to develop the MSW utilization methods [5]. One of the most modernized methods of municipal waste management is the thermal transformation of MSW-type waste in eco-incineration plants. The process of thermal treatment of municipal waste takes place in five stages: drying, degassing, incineration, gasification and afterburning. The use of an innovative method gives the possibility of electricity recovery. This process consists in heat exchange in a boiler where flue gases of reduced temperature heat the water flowing through the boiler as a result of which water vapor is produced which enters the turbine where the electricity is generated [6]. The thermal waste incineration process is increasingly common and 
introduced to the economic market of countries around the world, but it also involves the production of substances hazardous to the environment and human health. During the incineration of MSW, as mentioned earlier, apart from the MSW fly ash of (MSWFA municipal solid waste fly ash) numerous amounts of organic compounds and alkali oxides are produced, MSWFA also contains heavy metals: lead, zinc, copper and chromium [7].

\section{Fly ash from the HCFA group:}

High-calcium fly ash (HCFA) is the residue from the thermal treatment of municipal waste. It is also formed in the process of fossil fuel burning (hard coal and lignite). They are characterized generally by minimum of $10 \%$ calcium oxide content. HCFA can be classified into two groups. The first is low lime ash with a low content of burnt lime, consisting mainly of silicon oxide [8]. Due to the high content of minerals such as mullite and quartz, which are responsible for the morphology and crystalline phase, these ashes are very inactive [9]. The second group includes fly ash rich in large amounts of calcium oxide, where the crystalline phase consists mainly of calcium sulphates and carbonates, tricalcium aluminate and tetra-calcium aluminate sulphate [10]. There are four classes of fly ash activity:

- Inactive $(<3,5 \% \mathrm{CaO})$

- Low activity $(3,5-7 \% \mathrm{CaO})$

- $\quad$ Active (7-14\% CaO)

- $\quad$ Very active $(>14 \% \mathrm{CaO})$

\section{Mineral Carbonation Process}

The mineral carbonation process is a reaction that occurs spontaneously in the natural environment, but its kinetics as well as its speed are very slow, which results in a low value of the final efficiency of the process [11]. Therefore, in laboratory conditions, the mineral carbonation process is carried out under increased pressure and also at a higher temperature. It is the reaction between calcium oxide and carbon dioxide which results in carbonates, which are raw material for use in industry, as well as for further physical and chemical treatment [12]. There are two types of mineral carbonation:

- Direct:

$$
\begin{array}{ll}
\mathrm{CaO}+\mathrm{CO}_{2} \Rightarrow \mathrm{CaCO}_{3} & \Delta \mathrm{H}=179 \mathrm{~kJ} / \mathrm{mol}[13] \\
\mathrm{MgO}+\mathrm{CO}_{2} \Rightarrow \mathrm{MgCO}_{3} & \Delta \mathrm{H}=118 \mathrm{~kJ} / \mathrm{mol}[13]
\end{array}
$$

- Intermediate:

$\mathrm{CaO}+\mathrm{H}_{2} \mathrm{O} \Rightarrow \mathrm{Ca}(\mathrm{OH})_{2}$

$\mathrm{Ca}(\mathrm{OH})_{2}+\mathrm{CO}_{2}=>\mathrm{CaCO}_{3}+\mathrm{H}_{2} \mathrm{O}$

$\mathrm{MgO}+\mathrm{H}_{2} \mathrm{O} \Rightarrow \mathrm{Mg}(\mathrm{OH})_{2}$

$\mathrm{Mg}(\mathrm{OH})_{2}+\mathrm{CO}_{2}=>\mathrm{MgCO}_{3}+\mathrm{H}_{2} \mathrm{O}$

There is a possibility of previous treatment of the examined fly ash (grinding, cleaning) before the mineral carbonation process, as well as the use of catalysts changing e.g.: pH. However, these methods involve a large financial outlay, that is why most research groups resign from their use [15].

\section{MATERIAL AND METHODS}

The aim of the study was to conduct a process of mineral carbonation of fly ash coming from a
$\Delta \mathrm{H}=-68 \mathrm{~kJ} / \mathrm{mol}[14]$

$\Delta \mathrm{H}=-37 \mathrm{~kJ} / \mathrm{mol}[14]$

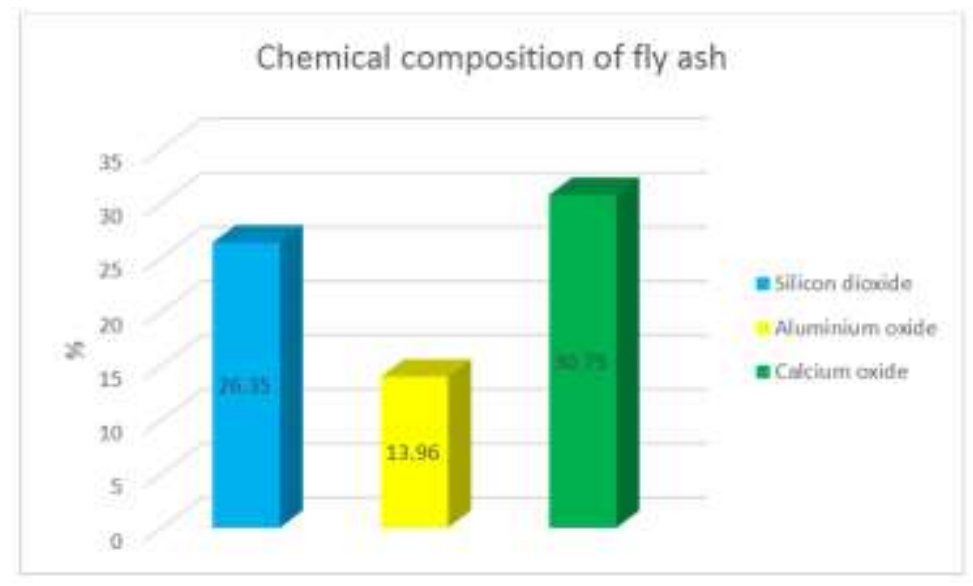

Fig-1: Chemical compositions of fly ash

Source: own research 


\section{The process of Mineral Carbonation}

A test sample was put in a reactor and degassed using a vacuum pump. Carbon dioxide was dosed into the reactor where the fly ash was located. The thermostat was used to maintain a constant temperature in the reactor throughout the mineral carbonation process. The process was carried out at three different temperatures: $298,323,348 \mathrm{~K}$ as well as under carbon dioxide pressure in the range of 0.2 to 1.6 MPa. After the end of the experiment, the fly ash material was subjected to further analyses and $\mathrm{CaO}$ determination.

\section{Measurements}

To determine the changes in physical parameters that took place during the carbonation process, reports were prepared to present the change in the pressure of carbon dioxide contained in the apparatus. Table-1 shows how the pressure was changed.

Table-1: Characteristic of pressure value during the mineral carbonation process

\begin{tabular}{|l|l|l|l|l|}
\hline Mass [g] & Temperature [K] & \multicolumn{3}{|c|}{ Pressure [MPa] } \\
\hline 413,00 & 298 & 0,239 & 1,133 & 1,665 \\
\hline 413,00 & 343 & 0,272 & 1,151 & 1,608 \\
\hline 413,00 & 348 & 0,468 & 1,172 & 1,671 \\
\hline \multicolumn{4}{|c}{ Source: own research } \\
\hline \multicolumn{4}{|c|}{}
\end{tabular}

\section{Instrumental Analysis}

The tested samples were subjected to X-ray analysis - XRD to identify the crystalline phase and composition of the material, infrared spectroscopy - IR to determine the transmittance and absorbance capacity of the tested samples depending on the temperature at which the mineral carbonation process was carried out, and scanning electron microscopy-SEM, to identify the shape and size of the particles of which the sample consisted.

\section{RESULTS AND DISCUSSION X-Ray Diffraction}

X-Ray Diffraction was made by Philips X'pert avalanche photodiode diffractometer with a PW 3020 goniometer, a $\mathrm{Cu}$ tube, and a graphite monochromator. Fig-2 shows fly ash which was before the mineral carbonation process. The next Figures 3, 4 and 5 presented a sample fly ash after the mineral carbonation process in higher temperatures: $298 \mathrm{~K}, 323 \mathrm{~K}$ and 348 $\mathrm{K}$.

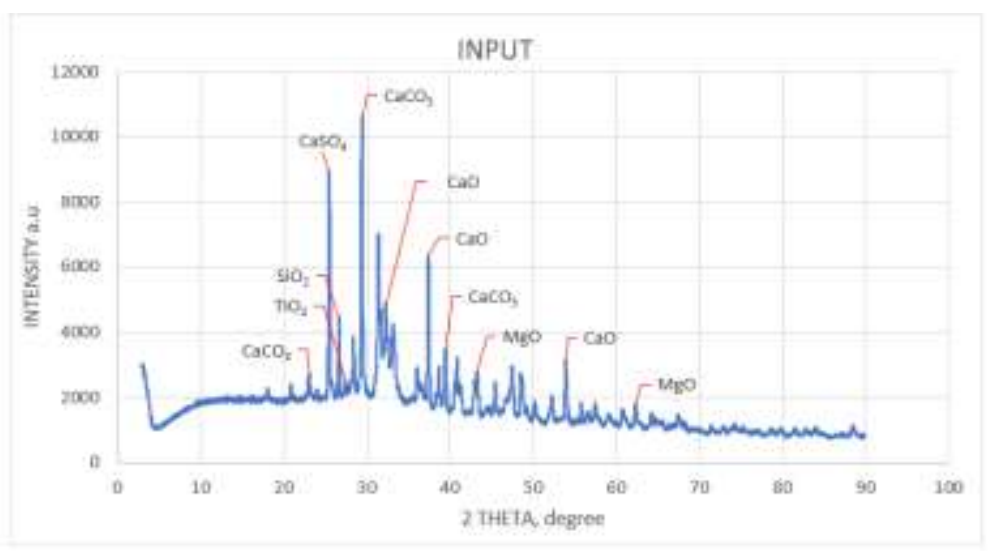

Fig-2: X-Ray Diffraction fly ash, before the mineral carbonation process Source: own research

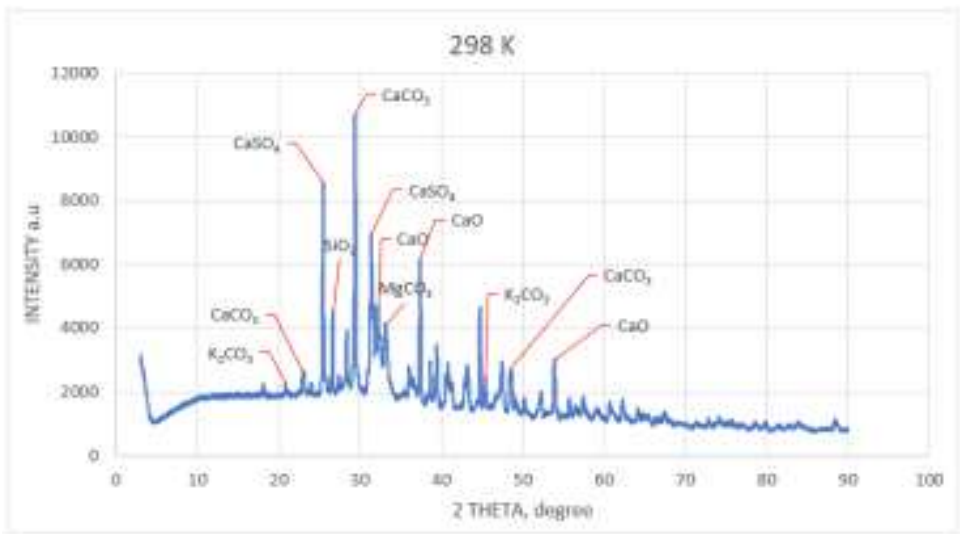

Fig-3: X-Ray Diffraction fly ash, after mineral carbonation process in $298 \mathrm{~K}$ Source: own research 


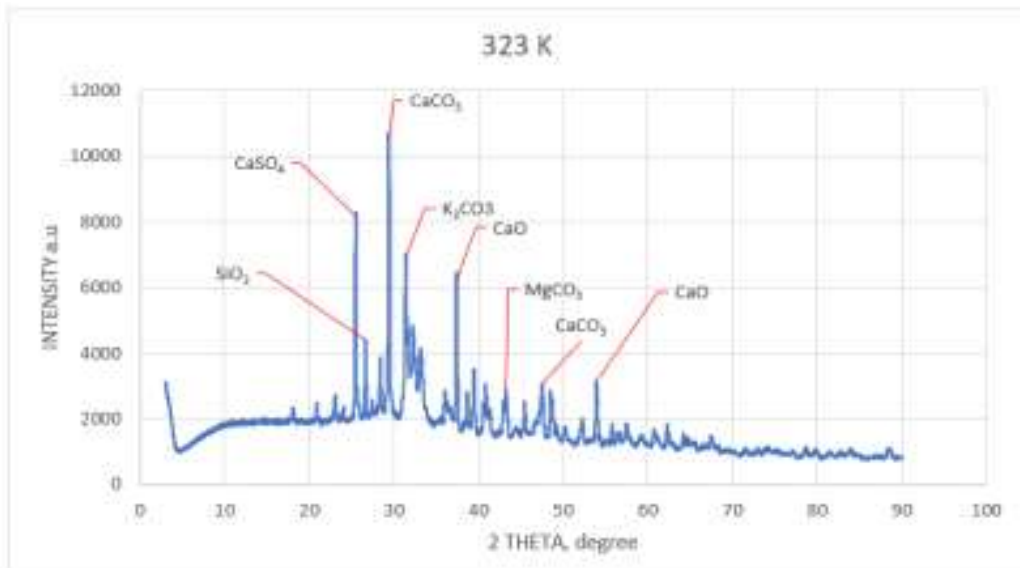

Fig-4: X-Ray Diffraction fly ash, after mineral carbonation process in $323 \mathrm{~K}$ Source: own research

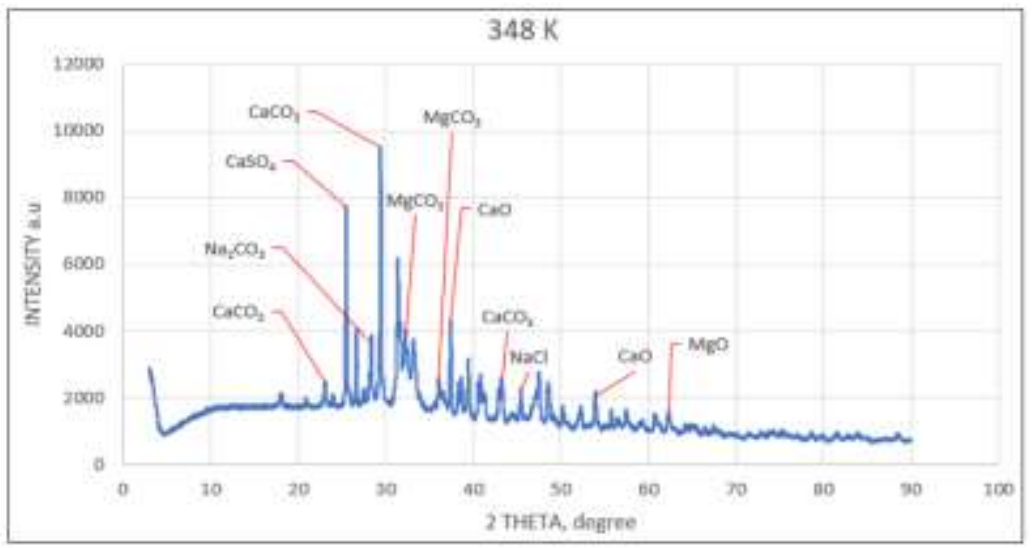

Fig-5: X-Ray Diffraction fly ash, after mineral carbonation process in $348 \mathrm{~K}$ Source: own research

From XRD data analysis it is possible to see that the crystal structure fly ash was changed. Before the mineral carbonation process (Fig-2), high calcium fly ash consisted of mainly from calcium oxide, magnesium oxide, calcium sulfate and silicon dioxide. After the mineral carbonation process (Fig 3, 4 and 5) obtained a new crystal structure that took part in building fly ash carbonates e.g. magnesium carbonate, potassium carbonate, calcium carbonate (the crystal structure has been increased) and sodium carbonate.

\section{Infrared Spectroscopy}

The samples were analyzed in infrared IR, in the wavelength range from 400 to $4000 \mathrm{~cm}^{-1}$. Fig-6 shows characteristic spectra fly ash before and after carried out the mineral carbonation process. The analysis used: Fourier-transform infrared (FTIR) spectra the raw materials and synthesized material with a Thermo Nicolet 380 FTIR spectrometer.

- $724-954 \mathrm{~cm}^{-1}-\mathrm{CaCO}_{3}$

- $1400 \mathrm{~cm}^{-1}-\mathrm{CaO}$

- $450 \mathrm{~cm}^{-1}-\mathrm{SiO}_{2}$

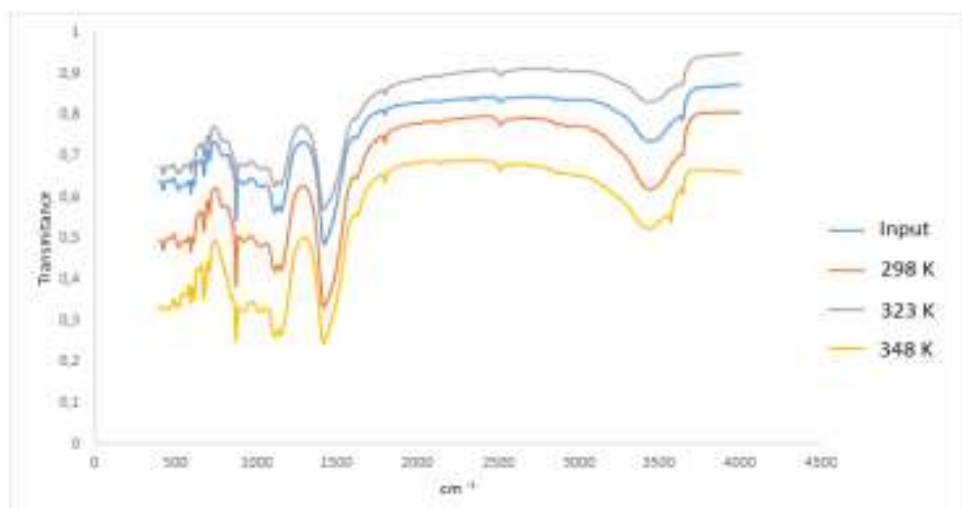

Fig-6: Infrared spectroscopy fly ash samples before and after the mineral carbonation process Source: own research 
The results of carried out infrared spectroscopy (Fig-6) obtained characteristic infrared spectra for calcium oxide and calcium carbonate whose posed an aim of the research. It would be also interesting to pay attention to how increasing temperature used to conducted mineral carbonation has influenced the transmittance value. In almost every case the transmittance value intensity has decreased.

\section{SEM Scanning Electron Microscopy}

The fly ash was analyzed by NOVA NANO SEM 200 (manufacturer FEI EUROPE COMPANY).

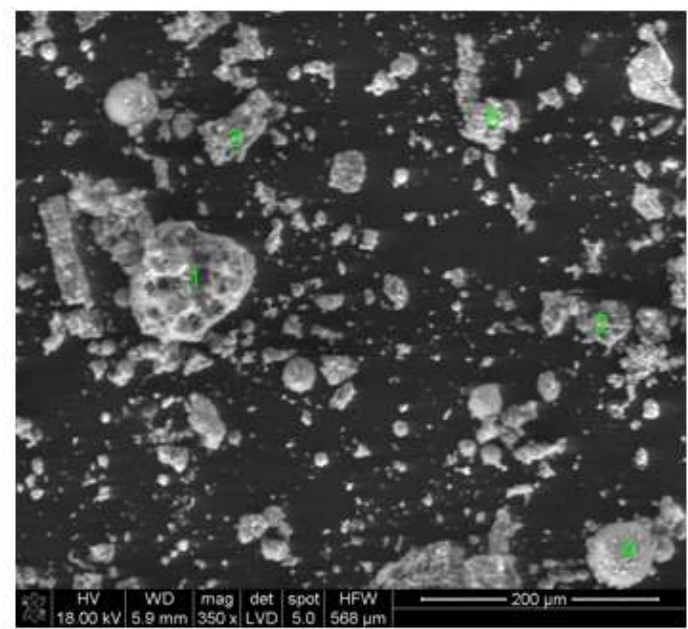

A

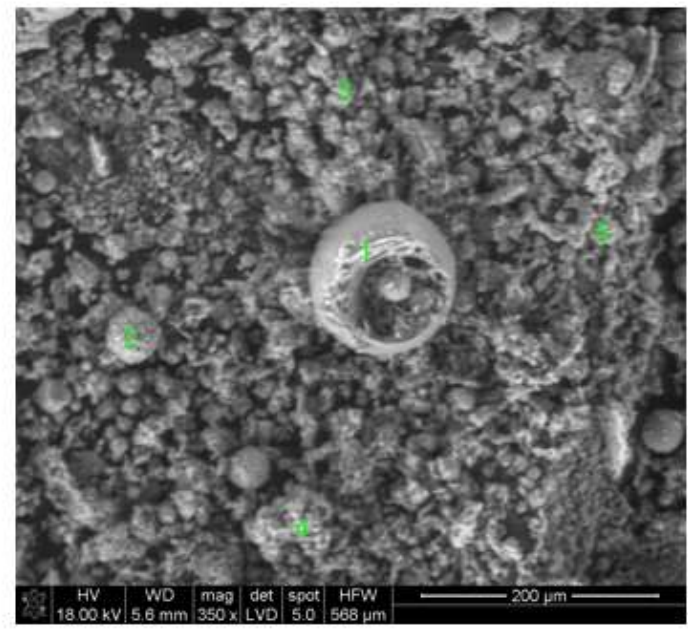

c
Due to scanning electron microscopy, it was possible to see fly ash grain. Figure 7C shows that the grain is consists of inner glass matrix and out glass matrix, which indicates the presence of aluminosilicate glass in the tested material, in a spherical form. Additional analysis is needed to test the composition of the rough surface visible in the picture. Figure 7A, presented fly ash before the mineral carbonation process, next the Fig. 7B, 7C and 7D show fly ash after reaction in higher temperature and elevated pressure carbon dioxide.

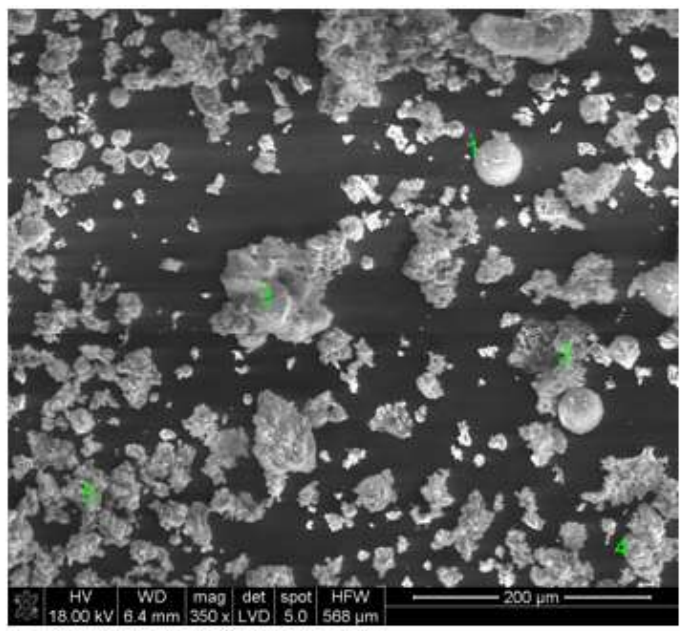

B

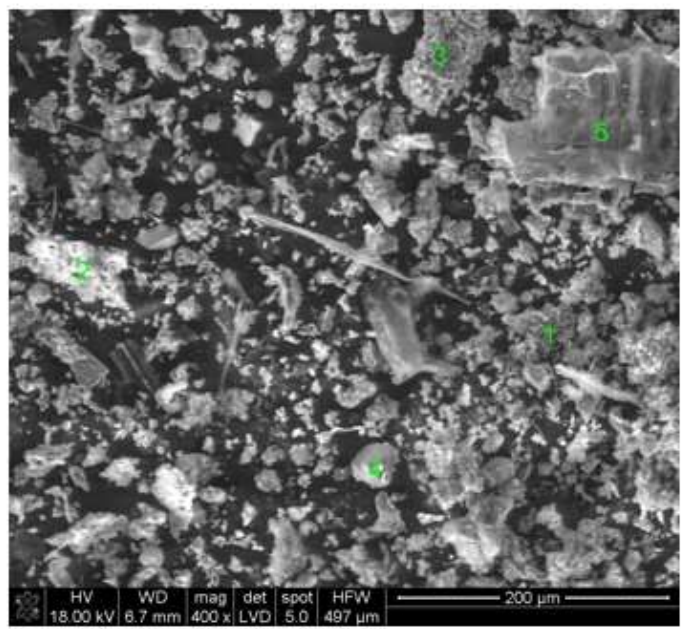

Fig-7: SEM pictures of the samples: A) starting material, B) carbonated in $298 \mathrm{~K}$, C) carbonated in $323 \mathrm{~K}$, D) carbonated in 348K

Source: own research

\section{Determination of Free Calcium}

Fig- 8 shows how temperature increased has influenced on consist of free calcium in high calcium fly ash. The amount of free calcium in the test samples was determined before and after the mineral carbonation process according to EN 451-1:2017 (E) [16]. 


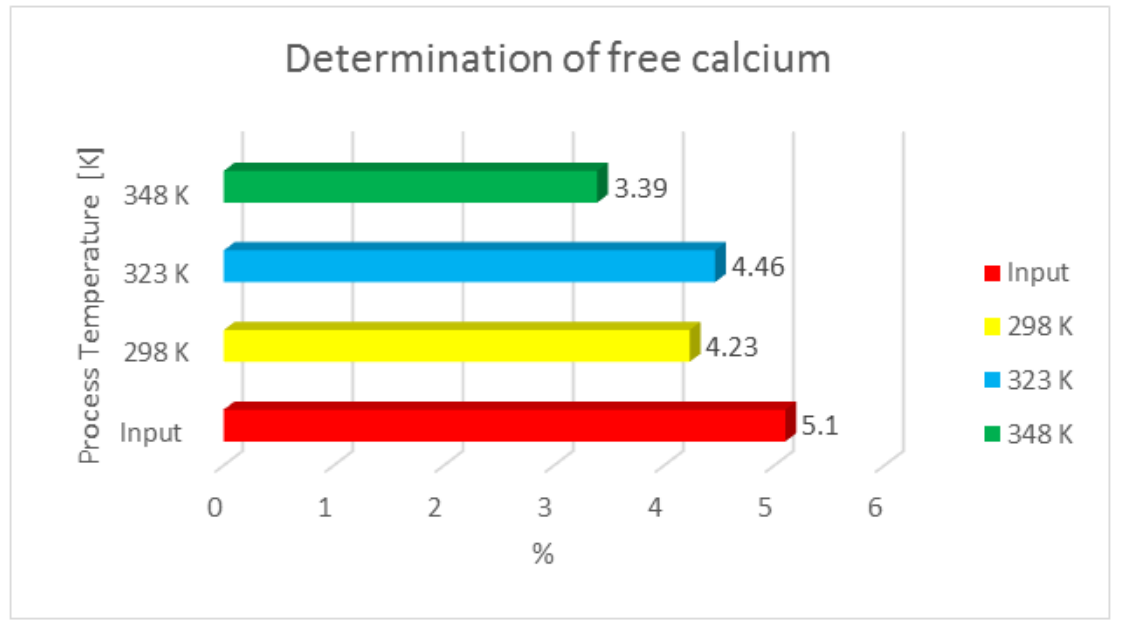

Fig-8: Determination free calcium

Source: own research

The highest estimated sequestration capacity was obtained in fly ash after the mineral carbonation process in $348 \mathrm{~K}$. The contents of free calcium in high calcium fly ash has been decreased by about $33,53 \%$.

\section{Impact}

The aim of the work was to pay attention to the growing problem of high-calcium fly ash from municipal solid waste thermal treatment plants. The mineral carbonation process allows to use fly ash as one of the substrates of chemical reaction. This makes it possible to manage it properly and use as a new material in industry in accordance with current standards. Moreover, it is an innovative opportunity to protect the environment from growing emissions of carbon dioxide.

\section{CONCLUSIONS}

The process of mineral carbonation is safe for the environment but above all for humans. It allows not only fly ash from the HCFA group to be used as one of the substrates of a chemical reaction but also carbon dioxide. As a result of the experiment, permanent carbonates were obtained, but also other chemical compounds. During the mineral carbonation process, the crystalline structure of ash was changed. The introduction of the process of mineral carbonation on the state market not only opens up opportunities for environmental protection but also creates new branches of the economy dealing with the disposal of hazardous and harmful waste.

\section{ACKNOWLEDGEMENTS}

This work was supported by AGH University of Science and Technology Grant Research Fund No. 16.16.210.476.

\section{REFERENCES}

1. Lu, J., Chang, Y., Poon, C.S., \& Lee, D. J. (2020). Slow pyrolysis of municipal solid waste (MSW): A review. Bioresource Technology, 123615.
2. Sathish, T., Bala Subramanian, D., Muthukumar, K., \& Karthick, S. (2020). Air pollution control water heater by using paraffin wax from municipal wastes. Materials Today: Proceedings.

3. Qiu, Q., Jiang, X., Lv, G., Chen, Z., Lu, S., Ni, M., ... \& Deng, X. (2018). Adsorption of heavy metal ions using zeolite materials of municipal solid waste incineration fly ash modified by microwaveassisted hydrothermal treatment. Powder Technology, 335, 156-163.

4. Zapotoczna-Sytek, G., Łaskawiec, K., Gębarowski, P., Małolepszy, J., \& Szymczak, J. (2013). Popioły lotne nowej generacji do produkcji autoklawizowanego betonu komórkowego. Warszawa: Wydawnictwo Instytut Ślacki Sp. z oo. 53-56.

5. Kalogirou, E., Themelis, N., Samaras, P., Karagiannidis, A., \& Kontogianni, S. T. (2010). Fly ash characteristics from waste-to-energy facilities and processes for ash stabilization. In ISWA World Congress. https://www.iswa.org/fileadmin/galleries/General $\% 20$ Assembly\%20and\%20WC\%202010\%2011\% 20Hamburg/Presentations/Kalogirou.pdf.

6. Krakowska, E. (2020). Zakład Termicznego Przekształcania odpadów w Krakowie. https://khk.krakow.pl/pl/ekospalarnia/ 26.06 (2020).

7. Shiota, K., Nakamura, T., Takaoka, M. Aminuddin, S. F., Oshita, K., \& Fujimori, T. (2017). Stabilization of lead in an alkali-activated municipal solid waste incineration fly ashPyrophyllite-based system. Journal of environmental management, 201, 327-334.

8. Sobala, J., Czuma, N., Zabierowski, P., Ćwik, A., Casanova, I., \& Zarębska, K. (2019). The process of mineral carbonation of fly ash with a high content of calcium oxide from the group HCFA, Vienna young Scientists Symposium. 102-103.

9. Filipiak, J. (2013). Wykorzystanie ubocznych produktów spalania jako stabilizatora do gruntów 
organicznych. Rocznik Ochrona Środowiska. 15:1153-1163.

10. Szadkowski, P. (2002). Aktywny popiół lotny a wzmocnienie podtorza. Zeszyty Naukowe. Budownictwo / Politechnika Śląska z. 95, Politechnika Wrocławska. 493-502.

11. Ji, L., Wang, X., Grigore, M., French, D., Gözükara, Y.M., Yu, J., \& Zeng, M. (2017). $\mathrm{CO}_{2}$ sequestration by direct mineralisation using fly ash from Chinese Shenfu coal. Fuel Processing Technology. 156:429-437.

12. Ćwik, A., Casanova, I., Rausis, K., Koukouzas, N., \& Zarębska, K. (2018). Carbonation of highcalcium fly ashes and its potential for carbon dioxide removal in coal fired power plants. Journal of Cleaner Production. 202:1026-1034.

13. Uliasz-Boheńczyk, A., \& Mokrzycki, E. (2014). Mineralna karbonatyzacja przy zastosowaniu surowców mineralnych- metoda redukcji $\mathrm{CO}_{2}$. Gospodarka Surowcami Mineralnymi - Mineral Resources Managment. 30(3):99-110.

14. Majchrzak, A., Majchrzak-Kucęba, I., \& Nowak, W. (2010). Mineralna karbonatyzacja jako jedna z możliwości sekwestracji CO2. http://www.planrozwoju.pcz.pl/dokumenty/konferencja/artykuly/1 9.pdf.

15. Ćwik, A., Zarębska, K., Baran, P., \& Szczurowski, J. (2017). Mineralna karbonatyzacja wysokowapniowego popiołu lotnego w warunkach podwyższonej temperatury i ciśnienia. Przemyst Chemiczny, 96(9).

16. British Standards Institution. (2005). Fly ash for concrete-Part 1: Definition, specifications and conformity criteria. 